\title{
Vicarious Mothers in Fascist Regime Cinema
}

Patrizia Bettella ${ }^{1}$

The Fascist regime proclaimed that women's preeminent roles were those of wife, mother, and breeder of numerous children for the Fatherland. Regime policies and Catholic precepts contributed to the myth of motherhood and the image of the mother became the central icon of Fascism. And yet we find a relatively limited number of documentaries and commercial films centring on motherhood. In commercial films it is remarkable to find that some maternal melodramas focus on the vicarious mother, a generous, selfsacrificing woman, who acts as the mother to a child who is not her own. After examining Gennaro Righelli's La canzone dell'amore, a precursor, I look at two films by Amleto Palermi, Le due madri and La peccatrice, where the female figure is a wet nurse. In Piero Ballerini's La fuggitiva and Ferdinando Maria Poggioli's Sissignora, the surrogate mother, a young orphan with no parental experience, is juxtaposed with the biological parent, who is portrayed as a bad mother. The self-centred, transgressive biological mother contrasts with the exemplary vicarious mother who, like a Marian figure, is willing to sacrifice herself for the good of her putative child.

\section{Introduction}

When talking about motherhood in commercial cinema of Fascist regime years, what immediately comes to mind is the famous tune Mamma sung by Beniamino Gigli in Guido Brignone's eponymous film released in 1941. The song evokes the maternalist politics of the regime, and is a fitting soundtrack for a time of renewed interest in motherhood at the cinema. The song is forever present in the Italian subconscious and is emblematic of the adoring reverence of the adult son for the mother and of the mother-son oriented culture that characterizes Italian society to this day $^{2}$. Brignone's melodrama presents as the heroine of the story an aging mother (Emma Gramatica), who does anything to save the marriage of her only son from the danger of adultery.

This essay looks at how Fascism controlled motherhood and celebrated the maternal ideal, and then focuses on the depiction of motherhood in regime cinema. Given the relatively limited

\footnotetext{
${ }^{1}$ University of Alberta, Canada.

${ }^{2}$ My thanks to Marianne Krajicek for editorial work on this article. The refrain of the song by Bixio and Cherubini is quite telling : «Mamma/ solo per te la mia canzone vola/mamma/ sarai con me tu non sarai più sola !/ Quanto ti voglio bene/ queste parole d'amore/ che ti sospira il mio cuore/ forse non s'usano più/ Mamma !/ Ma la canzone mia più bella sei tu !/ Sei tu la vita/ e per la vita non ti lascio mai più ».
} 
number of commercial movies centering on motherhood, it is remarkable to find that some of them, particularly in the last years of the Fascist rule, deal with the vicarious mother, a woman who is not the child's biological parent. In films by Amleto Palermi, Piero Ballerini and Ferdinando Maria Poggioli the surrogate, an exemplary woman extolled for her generosity, selfabnegation and sacrifice, contrasts the biological mother, who is depicted as flawed, selfish and immoral.

\section{Fascist Woman as Mother}

The image of the woman as mother was the central icon of Fascism. Under Fascism woman had a public mission in maternity and fertility, and could accomplish it only by producing children to strengthen the power of the state. According to Fascist ideology, women best fulfilled themselves in the domestic sphere and should conform to the model of the angel of the house, preserver of family and bearer of children (madre e sposa esemplare). Maternity within wedlock was promoted both by the Catholic Church and by the Fascist regime. Italian women had to conform to principles of modesty, subordination and self-sacrifice, values that were exalted in propaganda and in the paternalistic stance of the Catholic Church. In the Encyclical Casti Connubii (1930), Pope Pius XI declared that the only social function of the woman was matrimony, and that working outside the house was a perversion of the female character and of maternal dignity. The regime promoted the model of the robust, rural woman, healthy in body and spirit, who could bear many children for the Fatherland ${ }^{3}$. The Fascist regime redefined the role of paternity and maternity and created institutions such as the Opera Nazionale Maternità e Infanzia [National Institute for Mother and Child Welfare] (ONMI), a para-state organization that provided assistance and education to women, mothers and children. In the 1930s this institution became

\footnotetext{
${ }^{3}$ For women and maternity in Fascist regime see : Marina ADDIS SABA, La corporazione delle donne. Ricerche e studi sui modelli femminili nel ventennio fascista, Firenze, Vallecchi, 1988 ; Cecilia DAU NOVELLI, Famiglia e modernizzazione in Italia tra le due guerre, Roma, Studium, 1994 ; Luisa PASSERINI,

«Costruzione del femminile e del maschile. Dicotomia sociale e androginia simbolica », in Angelo DEL BOCA, Massimo LEGNANI, Mario G. ROSSI (dir.), Il regime fascista. Storia e storiografia, Bari, Laterza, 1995. See also the influential monograph by Victoria DE GRAZIA, How Fascism Ruled Women. Italy 1922-1945, Berkeley, Los Angeles, University of California Press, 1992. See also : Patrizia DOGLIANI, Il fascismo degli italiani, una storia sociale, Torino, UTET, 2008. For an interesting take on maternity and breast-feeding as a biopolitical duty during the Fascist regime see Elizabeth DIXON WHITAKER, Measuring Mamma's Milk: Fascism and the Medicalization of Maternity in Italy, Ann Arbor, University of Michigan Press, 2000.
} 
the central piece of the demographic campaign and provided an important lead for the role of women in society. The program of social assistance made of maternity a national duty and of breast-feeding its centerpiece ; nursing was considered the basis for woman's physical and spiritual health, and a natural right of the child. The programs of ONMI were designed to provide help to women in need, both married and single. The institution protected maternity and childhood and juxtaposed it against contraception, child abandonment, and abortion. ONMI also aimed at controlling mothers' behaviours and provided unprecedented assistance, such as welfare for single mothers, who could keep their children and avoid the illegal and dangerous practice of abortion, punishable by Fascist laws and a taboo for the Catholic Church. Lesley Caldwell notes that state regulation of motherhood is ambivalent, since the concern with maternity is in fact a concern with children and the nation, and only indirectly with women as mothers, relegating women to a marginal position, and equating their identity with motherhood ${ }^{4}$. The public cult of motherhood was reinforced with numerous initiatives such as the institution of a special day to honour mothers : Mother's Day celebrations were initiated in December 1933 and held on Christmas Eve, a day that was predicated on the Catholic cult of the Virgin Mary, thereby conflating the concept of motherhood with the mother of God, the Virgin's chastity and the sacrifice of her only son. As De Grazia observes, it was « an occasion to ponder the ancient Italian cult of the Mater Matuta and the self-abnegation example of the Madonna $»^{5}$. Even in Mussolini's speeches the mythology of maternity centred around the good mother as a good patriot, and child bearing as a national duty. The woman embodied the continuation of the race, and her purpose was first to procreate and then to educate her children. The exaltation of the woman as creator of many children and future soldiers for the Fatherland, puts the mother at the service of the nation, an honor for which she is recognized. This privileged position of the mother is tied to the special role she assumed during the Italian unification ; mothers of Garibaldi, Mazzini and of the Cairoli brothers, became the object of a quasi-religious devotion in the new nation. The absolute dedication of the mother to the son derives from the sacred mission of the son which, in

\footnotetext{
${ }^{4}$ Lesley CALDWELL, ( Madri d'Italia : Film and Fascist Concern with Motherhood », in Zygmunt BARANSKI, Shirley W. VINELL, (dir.), Women in Italy : Essays in Gender, Culture and History, New York, St. Martin's Press, 1991, pp. 43-63) examines the LUCE film Madri d'Italia (1935), a silent documentary that emphasizes specific groups of women (lower social class and peasants), and plays on their maternal fears to promote the use of the ONMI, urging them to devote themselves completely to child care using a tone of correction and authority.

${ }^{5}$ V. DE GRAZIA, How Fascism Ruled Women, op. cit., p. 31.
} 
turn, guarantees the sacralisation of the figure of the mother. Also the myth surrounding Mussolini's mother, Rosa Maltoni, contributed to the cult of motherhood during the regime. Mussolini himself was considered the embodiment of both the virility and the femininity of the exceptional leader, whose last name began with an $\mathrm{M}$, the initial of the word mamma, as young children were taught in school ${ }^{6}$.

The Fascist revolution was poised to construct an idea of the family whereby the man was the head of the family and the woman was mother and exemplary wife, subordinated to her husband, to the regime and to its Duce. Mussolini himself considered the family an institution in danger and decline, due to the vanity and hedonism of the urban upper middle class. The new propaganda focussed on making maternity attractive and profitable, by offering incentives and special honors to prolific mothers. However, in the rapidly changing Italian society of the Thirties and Forties many women began to move from the country to the city to find employment and entered the workforce, achieving a form of independence that contrasted with the model of Fascist womanhood. This resulted in a tension between traditional values and modernity, between country life and city life, married family women and single working women.

\section{Regime Cinema and the Mother}

When examining the role of mothers in Fascist film, one ought to distinguish the output of commercial cinema from the documentaries and newsreels produced by LUCE, L'Unione Cinematografica Educativa [The Union of Educational Film], the organization created in the 1920s to educate the population through film propaganda, that became compulsory viewing in every cinema. Since the mother was exalted as the creator of new Italians, in the LUCE documentaries we see the celebration of regime interventions in support of maternity.

We notice contradictory representations of women during Fascism : media, cinema, newspapers, magazines and products of the cultural industry propose various models of femininity that do not always conform with the ideal promoted by the regime. Official rhetoric emphasized the new woman as wife and mother, but there were other representations of women in circulation -

\footnotetext{
${ }^{6}$ For L. PASSERINI ( Costruzione del femminile e del maschile. Dicotomia sociale e androginia simbolica », op. cit.) this importance of the mother is distinctive of Fascism, in contrast with Nazism, where the leader does not have a preferred feminine image ; Hitler's feminine ideal is not a real woman, rather Germany, as a symbolic female figure.
} 
particularly in cinema, strongly influenced by American films - where many different options for women were presented ${ }^{7}$.

Considering the rise of Italian cinema during the Fascist regime, and Mussolini's idea of cinema as the most potent weapon of propaganda, one notices that the dominant genre in commercial cinema of the time is light comedy, the white telephone or déco movies ; to be sure, in the telefoni bianchi women were protagonists, but they rarely appeared as mothers ${ }^{8}$. This lack of mothers and children in commercial films of the Regime, up to the late 1930s, stands in stark contrast with a Fascist ideology centred on the cult of the large, healthy family, and the mythologizing of motherhood. Grignaffini believes that the scarcity of mothers in feature films derived from the presence of repertories of propaganda documentaries ${ }^{9}$. Motherhood was mythologized through the Cinegiornali - the newsreels that, from 1927 onwards, were shown in all the movie theaters and projection halls before the regular movie screenings started. In LUCE newsreels and documentaries of the 1930s, mothers are shown for purely didactic purposes : to illustrate and show the efficacy of the welfare system. Maternity is presented as a social fact, as a factory of the future. In the Cinegiornali, mothers symbolize the masses, the spirit of sacrifice and subordination to the patriarchal authority of the husband and of the Duce. Interestingly, such newsreels do not depict the bourgeois family with one child, but rather the great masses and peasants, those who married the most and had the most children. In turn, LUCE newsreels rarely mention working class women, textile workers, secretaries or teachers. Carlota Coronado observes that almost half of the LUCE newsreels relating to motherhood talk about state and ONMI initiatives to promote maternity, social and medical assistance to all mothers and especially to children. The propaganda focuses on the positive results and not on the quality of the programs, because the regime wants to convey the idea of progress, showing modern structures, centres that support maternity, and the healthy children, who are the future of the nation. In fact, the real protagonists of these newsreels are the children, while the mothers always appear as passive. When ONMI

\footnotetext{
${ }^{7}$ In many white telephone movies, influenced by American and Hungarian comedies, we see young, single women moving to the city and working as secretaries, phone operators, typists, salespersons, as models. See for example chapter 3 of Meris NICOLETTO's book Donne nel cinema di regime. Fra tradizione e modernità, Alessandria, Falsopiano, 2014.

${ }^{8}$ For Fascist-regime cinema and dèco movies see the seminal work of Gian Piero BRUNETTA, Cent'anni di cinema italiano. Dalle origini alla seconda guerra mondiale, Bari, Laterza, 2011, and Il cinema italiano di regime. Da 'La canzone dell'amore' a'Ossessione' 1925-1945, Bari, Laterza, 2009.

${ }^{9}$ Giovanna GRIGNAFFINI, «Il volto e la divisa. Luoghi del femminile nel cinema italiano degli anni Trenta », in Id., La scena madre. Scritti sul cinema, Bologna, Bononia University Press, 2002, p. 246.
} 
centres are featured in the news, the babies are not shown together with their mothers, but rather in the care of nurses or nuns in modern, clean, and orderly nurseries. Maternity is reduced to a celebration of fecundity ${ }^{10}$. In reports about the celebration of the "Giornata della Madre e dell'infanzia » prolific mothers are honoured for the number of live births, but they are not recognized with their own name, they lack individuality as women, because they are not valued as persons, but as makers of babies.

While LUCE newsreels devote some space to the promotion of motherhood and to the glorification of the prolific families, in commercial cinema mothers begin to emerge as a significant presence in the late 1930s and early 1940s, with the rise of film melodrama, the genre par excellence centred on the figure of the mother ${ }^{11}$.

Up to the early 1930s the most significant Fascist movies, such as Alessandro Blasetti's Terra madre (1931), and Giovacchino Forzano's Camicia nera (1933), do not deal with motherhood. Blasetti's film, aimed at promoting rural over urban values, despite mentioning the mother in the title, does not devote a major role to a mother ; motherhood is in fact a symbolic designation of the land. The film is defined as the " esaltazione della figura del padre-patriarca-capo (ducaduce) ». (Exaltation of the figure of the father-patriarch-leader (duke-Duce) ${ }^{12}$. Similarly, Forzano's Camicia nera (1933), a propaganda film made by the LUCE to celebrate the first decade of the Fascist regime, and considered a docu-drama of the birth and rise of the Fascist regime, does not tackle the theme of motherhood. In the first part, when the husband leaves for the

\footnotetext{
${ }^{10}$ Carlota CORONADO, «Esposa y madre exemplar : la maternidad en los noticiarios Luce durante el fascismo (1828-1945) », in Historia y Comunicación Social 13 (2008), pp. 5-31. Cinegiornali reported for example on the "Celebrazione della madre e del fanciullo » (Celebration of the mother and child) that took place in Rome in December 1936, on the inauguration of the «Casa della Madre e del fanciullo » (House of the mother and child) in Pisa in June 1936, and on the visit to the "Casa dell'Opera Nazionale Maternità e Infanzia » (House of the National Institution for Mother and Child Welfare) in Modena in October 1937. The LUCE Archives are available online at www.archivioluce.com

${ }^{11}$ For more on melodrama at the movies, see Lucia CARDONE's book Il melodrama, Milano, Il Castoro, 2012. See also Orio CALDIRON, «Il mélo tra vecchio e nuovo », in Ernesto LAURA, Storia del cinema italiano. Vol. 4, 1940/44, Venezia, Roma, Marsilio Edizioni di Bianco \& Nero, 2010, pp. 187-203. The mother will become more and more important in the post-war years, starting with Anna Magnani in the role of Pina in Rome, Open City and Bellissima and later with Sophia Loren in Two Women.

${ }^{12}$ Quote from Il Morandini. Dizionario dei Film (Bologna, Zanichelli, accessed online :

http://trovacinema.repubblica.it/film/terra-madre/119099). Interestingly enough, the scarcity of mothers is also noted in pre-war films of the Nazi era, as indicated in Jo FOX's article « 'Everyday Heroines' : Nazi Vision of Motherhood in Mutterliebe (1939) and Annelie (1941)», Historical Reflections 2 (2009), pp. 21-39.
} 
war, the wife/mother is shown as helpless and passive, while her little son is strong and proud of his father's heroism and is motivated to go looking for him, when he goes missing at the end of the war.

\section{Maternal Melodramas}

In commercial cinema motherhood gains new ground with the rise in popularity of the melodrama. As an effect of autarky and of the legge sul monopolio (1939), a law which caused a drastic reduction of foreign movies in the Italian market, Italian mélos become more common. Melodramas draw their narrative plots from popular literature, from the feuilleton, and from products of the cultural industry, such as magazines, illustrated newspapers and cineromanzi. All include an educational message for the female public : woman is trained to respect maternity and family.

Melodramas of the late 1930s and early 1940s present various maternal figures ranging from the mother/Madonna, the holy mother as Matilde Sarni, in Brignone's Mamma, or Rosalia in Ferdinando Maria Poggioli's La morte civile (1942) and Maria di Santafiore in Giacomo Gentilomo's Mater dolorosa (1942) ; to the mother outside of wedlock, portrayed as a sinner, the seduced and abandoned woman, left alone with her child, such as Maria Ferrante in La peccatrice by Amleto Palermi (1940). The sin of Anna Roberti, the fallen woman in Una storia d'amore (1942) by Mario Camerini, is only redeemed through her death. Needless to say, the mother-as-sinner is usually shown in her suffering, and ends up being severely punished for a behaviour which is considered immoral. Extra-marital maternity is connected to the contrast between eros (sensual love) and agape (conjugal love). In the woman-as-sinner films, the mother is punished for being solely responsible for the pregnancy, like Anna in Una storia d'amore, a woman with a shady past who, even after finding a husband and giving birth to a baby girl, dies shortly after childbirth. In È caduta una donna (1941) by Alfredo Guarini, Dina gives up her son, born out of wedlock, and later dies run over by a car. Only rarely, after the sexual transgression, can the single mother, through an exemplary conduct and expiation, hope for conjugal love. This is the case of Adriana in T'amerò per sempre by Mario Camerini. Very often, though, the finale shows the condemnation of the single mother, who cannot transform eros in apage, cannot free herself from the sin, and is not allowed to follow the path of redemption.

A more virtuous mother figure is the one who fulfills her destiny through sacrifice. Such a model of motherhood is found in Maria Bini, the young teacher in Giorgio Bianchi's La maestrina (1942) ; in Adriana, in T'amero per sempre (1943) and in Rosalia in Ferdinando Ma- 
ria Poggioli's La morte civile (1942). In sum, maternal melodrama in cinema produces films aimed at stimulating noble ideals and at demonizing sinful acts and nefarious passions, showing that vice leads to perdition, whereas virtue is rewarded. In the mélo films of the late Fascist years, the moral message is a warning to women to beware of the dangers and corruption of modern city life, in contrast to the traditional, wholesome life of the country.

Interestingly enough, the presence of the maternal figure in cinema of the late 1930s and early 1940s finds a parallel in popular songs of the same period. In the musical production of the 1930s, critics have noticed that the word mamma supplants the more austere madre. In the songs of the late 30s and 40s the term, mamma or mammina goes together with casetta (little home) and sposina (little bride) ; the bride and mother. Later on, in the war years, the bride and mother figure becomes the vecchietta, the old mother, anxiously awaiting the return of her son from the war. In some songs the mother is equated with the Madonnina (little Madonna) who becomes a symbol of the weeping mother, who is suffering for the loss of her son in $\operatorname{war}^{13}$.

\section{Vicarious Mothers}

In the maternal iconology of commercial cinema we find also the vicarious mother, a woman with strong maternal instincts, spirit of sacrifice, sense of abnegation and generosity - all qualities that lead her to nurture, protect and raise a child who is not her own. The vicarious mother makes her appearance in Gennaro Righelli's La canzone dell'amore (1930), the first sound movie in Italian cinema. This film is a precursor, in that it shows a mother type that will become both more prominent and more nuanced in late 1930s and early 1940s melodramas.

I will look at the precursor, La canzone dell'amore, and then analyze two movies by Amleto Palermi - Le due madri (1939) and La peccatrice (1940) - that present the vicarious mother as a wet nurse. Later I will focus on Luigi Ballerini's La fuggitiva (1941) and Ferdinando Maria Poggioli's Sissignora (1941), in which the putative mother is an orphan and unmarried woman, whose sacrifice becomes progressively more severe and whose virtuous conduct does not lead to reward. In some movies, the vicarious mother is deliberately juxtaposed with the biological parent, who is shown to be a bad example of motherhood. In Le due madri the putative mother is an aged woman, who has raised a child as her own, displaying self-sacrifice, generosity, and wis-

\footnotetext{
${ }^{13}$ See Pietro CAVALLO and Pasquale IACCIO, « La donna nella canzone italiana degli anni Trenta. Vecchi e nuovi miti », in M. ADDIS SABA, La corporazione delle donne, etc., op. cit., pp. 305-340.
} 
dom, that allow her adult son to live according to traditional principles. Vicarious mothers are often identified with the figure of the Virgin Mary, and display self-sacrifice and unconditional love for the child. At times, the vicarious mother is neither a mother nor a married woman, but possesses a natural motherly instinct, that can be stronger than that of the biological mother.

\section{A Precursor : Righelli's La canzone dell'amore}

Gennaro Righelli's La canzone dell'amore is noted in cinematography for its technical innovation, since it is the first sound movie in Italian cinema, and was simultaneously released also in French and German. The film became famous for the lead song Solo per te Lucia, dedicated to the protagonist. The plot is a free adaptation of the novella, In silenzio, by Luigi Pirandello ${ }^{14}$. It is the story of the sacrifice and sorrow endured by a young opera student, Lucia (Dria Pola), who, while living in Rome, discovers that, back in her home village, her mother has given birth to a baby boy out of wedlock, and died immediately afterwards, leaving the newborn baby all alone. Lucia's innate instinct is to take up a mothering role for the sake of the child. She gives up her music career and her relationship with Enrico, a talented musician, to take care of Ninni, the boy whom everyone believes to be her son.

The film opens with a scene resembling a wedding banquet, in which all the music students are celebrating the end of school, and Lucia and Enrico declare their love for one another and plan to spend their life together. As a sign of good fortune, a friend of the couple gives them a doll representing a baby. Lucia calls this baby 'nostro figlio'(our child). This doll proleptically hints at the arrival of a baby in Lucia's imminent future. In fact, shortly afterwards, Lucia discovers the existence of a new baby boy, her stepbrother, all alone and pennyless, since the boy's father, a married man, left when Lucia's mother became pregnant. Lucia has few resources, and is forced to take a job to raise her stepbrother by herself. She also disappears from Enrico's life, convinced that a boy would pose an obstacle to his rising career.

\footnotetext{
${ }^{14}$ In silenzio is the first novella in the collection, with the same title, of Luigi PIRANDELLO's Novelle per un anno. This group of stories was published in 1923 (Firenze, Bemporad), but In silenzio first appeared in 1906, published by Treves in Milan. The film is a free adaptation, since it does not follow the same plot of Pirandello. In Pirandello's story, the protagonist, who takes up the parental role, is a high school boy called Cesarino, who will take care of his baby brother when his mother dies in childbirth. In Righelli's film, it is Lucia who is called to the maternal role when her mother dies in childbirth.
} 
Lucia at first is inexperienced with the newborn baby, but she can see from her window, in an apartment across the street, a scene of domestic life : another mother, living in a normal family setting, taking care of a new baby and breastfeeding him ; while Lucia is aware of her difference, evident in her lack of breast milk, she can follow the example of her neighbor and still feed the baby, thanks to a baby bottle, an emblem of surrogacy. Lucia's motherly quality is anticipated by the earlier present of the baby doll. Lucia keeps this doll, symbolizing the putative son, even after she has left Enrico, and stores it in a chest of drawers in the modest apartment where she moves, after taking charge of little Ninni. Ninni calls Lucia 'mamma' and grows well, thanks to her care. But Ninni's father, who meanwhile has lost his wife and made a fortune, finds Lucia and claims his right over the son, who is now two years old. He offers Lucia the chance to live comfortably in his house with her little brother, but Lucia first refuses to give up the boy : «Ninni è mio. Per lui ho rinunciato a tutto... Né io, né il mio Ninni abbiamo bisogno di voi. Mia madre è morta di vergogna, di stenti e voi questo ricordo non potrete mai cancellarlo ». (Ninni is mine. I gave up everything for him... Ninni and I do not need you. My mother died in shame, in poverty and you cannot delete this memory).

But the man states the importance for the boy to have a father, so in the end Lucia succumbs to the rights of the patria potestà and agrees to give up her little brother, recognizing that the father can offer Ninni a wealthy life. In the melodramatic ending, on the day the boy is going to join his father, Lucia is desperate and is contemplating suicide. The vicarious mother has sacrificed everything for Ninni: she gave up her relationship, disappeared from her boyfriend's life, she took upon herself the shameful sin of a woman with a child born outside of wedlock, she had to abandon her music career and find a job to support the baby. In the most dramatic moment, when Lucia is about to jump off the balcony, Enrico, who discovered her predicament from the boy's father, arrives and saves her. In the finale, Lucia and Enrico are back together and the film concludes with hope for Lucia's future and for a family of her own. The happy ending is the promise of a bright life, one that Lucia deserved for being a woman who did not commit the sin of her mother. In fact, Lucia has paid the price for her mother's sin. The generous and virtuous mother figure, who is willing to sacrifice herself for the child, is rewarded in the end, by getting her love back. The adaptation from Pirandello's novella is quite loose ; in Righelli's film, the protagonist is the sister/surrogate mother, while in Pirandello it is a young man, the boy's brother, who takes up a parenting role towards his step-brother. The change of gender in the film is 
indicative of the importance attributed by Fascism to the promotion of exemplary motherhood, a theme that is absent from this novella by Pirandello ${ }^{15}$.

\section{Wet Nurses as Surrogate Mothers in Two Movies by Palermi}

It is not a coincidence that both Palermi's movies with vicarious mothers depict them as wet nurses. In the Fascist years the practice of breast-feeding, and of wet nursing, was made into a biopolitical duty, and was proclaimed the best way of raising healthy and strong babies for the nation. With the great emphasis on the value of the infants to the family, mothers were seen as intermediaries between children and the state. Breast-feeding was viewed as a sacred obligation of the mother. Depriving the infant of the mother's milk was considered a sin, because breast milk was a natural right of the child. By breast-feeding, the mother was participating in the glorious rebirth of the new Fascist nation. Children, whose mothers were gravely ill or deceased, were assigned by ONMI to a wet nurse or fed with other methods ; otherwise failure to breastfeed one's baby was a sign of bad motherhood ${ }^{16}$.

In Amleto Palermi's Le due madri (1938) the theme of duplicate motherhood is announced by the title, bringing to the fore the plight of the adult son, Salvatore Amodio (Vittorio De Sica), who discovers that he has two mothers. The woman he has been calling mother all his life, Mamma Rosa (Bella Starace Sainati), is in fact his wet nurse (balia), a simple and generous peasant, whose baby died at birth and who nursed and raised Salvatore after his biological mother failed to claim him and to pay for his care. Salvatore's biological mother is an example of bad mother: she abandoned her baby, did not breast feed him and put her career as a singer before motherhood. The entire film, which is a mix of comedy and melodrama and which was well received by the critics, ${ }^{17}$ pits the corrupt and frivolous life of the natural mother in the big city, against the simple and honest life and values of the country woman from the village of San

\footnotetext{
${ }^{15}$ The short story In Silenzio was first published in 1906. So it was written before Pirandello expressed his Fascist inclination that became clear in the 1920s.

${ }^{16}$ For more on Fascist discipline about maternity and child care see E. DIXON WHITAKER, Measuring Mamma's Milk: Fascism and the Medicalization of Maternity in Italy, op. cit., chapter 5.

${ }^{17}$ See Mario GROMO's review on La Stampa (December 3 1938), where the movie is praised for being above the average for its complexity. Dino FALCONI in Il Popolo d'Italia (November 18 1938) notes that the film reaches its best in the melodramatic scene at the hospital when the two mothers are assisting Salvatore injured when fighting in Spain.
} 
Biagio, where Salvatore was raised. Mamma Rosa was Salvatore's wet nurse, but when her child died and this baby was left to her and her husband, she raised him as her son, a gift sent by God to replace her dead baby, though Rosa was aware of the fact that one day the biological mother might come and claim him. Salvatore is called by everyone in the village «Il Signorino », to indicate his upper-class origin. Salvatore's real mother is Kiki Valeri (Lydia Johnson), a famous singer (canzonettista) with a colorful life, who had her baby out of wedlock and left him with the wet nurse, to pursue her career. This elegant and sophisticated woman appears very attractive and more sensual than her age.

Caldwell notes that in Regime representations of women there is a clear distinction between attractiveness and female sexuality, on the one hand, and desexualized images of women as mothers, worn down by child-bearing, unable or too old to care for their appearance, on the other. The latter images reflect lower class women, who are too old to be sexually attractive ${ }^{18}$. Salvatore's biological mother, as an artist and entertainer, does not fit the mother image promoted by Fascism: she is not an exemplary wife, and she is not a completely asexual and de-eroticized being. Good mothers, in fact are shown as aging women, such as Matilde Sarni in Mamma, and Mamma Rosa in Le due madri ${ }^{19}$ (Figure 1). Bad mothers are depicted as more sophisticated, younger women, working outside the home in jobs that are not considered respectable (Figure 2). This is the case of Kiki Valeri, and also of Vanda Reni, the vain chanteuse, biological mother of little Marina in Ballerini's La fuggitiva, that is discussed below. In both movies the canzonettista, the transgressive and frivolous biological mother, is pitted against the putative one, who is a model of virtue and abnegation. Sexuality and motherhood do not go together in the Fascist ideology. ${ }^{20}$ In Le due madri Kiki, at the end of her singing career, and now a rich widow, is finally interested in finding her long-abandoned son, to reclaim him. However, Salvatore does not fit into the big city, or into the sophisticated setting of his biological mother's milieu. He also feels dominated and manipulated by Kiki, who wants him to become an artist, as if he could fulfill her artistic aspirations, now that she has ended her own singing career. Kiki

\footnotetext{
${ }^{18}$ L. CALDWELL, («Madri d'Italia : Film and Fascist Concern with Motherhood », etc.), op. cit., p. 49.

${ }^{19}$ Mamma Rosa is played by Bella Starace Sainati, the same actress who plays the role of the old mother in Palermi's La peccatrice.

${ }^{20}$ We find the contrast between motherhood and sexuality also in the music of the time. See, for example, the song Balocchi e profumi (1928) by E. A. Mario (pseudonimo di Giovanni Ermete Gaeta), in which the mother buys perfumes for herself, to enhance her attractiveness, and ignores the request of her little daughter to buy her a toy. The two aspects in this song are conflated in the same woman.
} 
wears elegant and colorful dresses, deemed unsuitable for her age, she is obsessed with her appearance and with concealing her real age. In one scene, she is shown in conversation with Salvatore, while tending to her make-up, in an attempt to keep looking young and attractive. Kiki, as her artificial and somewhat ambiguous name/nickname suggests, is the very opposite of Mamma Rosa, the plain, grey-haired, well-built peasant, who fits more into the mold of the massaia rurale (rural housewife), who is still strong enough to grow her vegetable garden, who mends her old shawl, and does not think she deserves the silk one gifted to her by Salvatore. Throughout the movie we see the affection, generosity and simplicity of the peasant vicarious mother, who appears to be more motherly than the biological one.

This film also features the motif of the mother of a soldier, since Salvatore, escaping the big city, the luxury and sophistication of Kiki's house, prefers to join the army with his friend Michele and go to fight the war in Spain. The celebration of military sacrifice was crucial to the Fascist ideology and the scenes showing the battle, which causes Salvatore's serious injury, despite the general lightness of this movie, hint at the heroic acts of the soldiers and of the courageous sufferings of their mothers. In Le due madri, Salvatore does not die, but is sent home for an operation. While Mamma Rosa is at Salvatore's bedside in the hospital, Kiki arrives to visit her son. At this point, his biological mother shows a change in attitude. She is a woman transformed. Salvatore is hesitant to accept her visit, and it is generous and selfless Mamma Rosa who convinces him to see his mother. Kiki looks very different now: more soberly dressed, she appears more aged and, more importantly, she is concerned about her son and his health. Kiki now realizes that she is alone and that Salvatore is all she has. This moment marks the definitive transformation of Kiki. Mamma Rosa, too, becomes aware of this change, particularly after the operation, when both women want to assist Salvatore, and the nurse announces that only the mother is allowed to stay with the recovering patient. Mamma Rosa points at Kiki, who is the biological mother, but Kiki steps back and, while she kneels to pray for her son in a chapel, she leaves Mamma Rosa at Salvatore's bedside. A similar, if more dramatic scene, featuring the child ill in bed, appears in La fuggitiva where Delfina, the vicarious mother, at the bedside of the feverish and delirious girl, Marina, generously steps back and sacrifices her own affection and feelings towards the child, to give space to the biological mother, who is not recognized by her daughter. Palermi's Le due madri has a happy-ending, in which the biological mother settles in the countryside with Salvatore's new family and Mamma Rosa. 
Remarkably, Palermi returns to the figure of the wet nurse a few years later in La peccatrice (1941), a film considered the emblem of Fascist melodrama, and a scandalous one, in that it is set in a brothel $l^{21}$. Here the traditional aging mother is opposed to the wayward daughter, who is a failed biological mother but tries to redeems herself by being an exemplary wet nurse. At the beginning of the film, Maria Ferrante (Paola Barbara), who works in a brothel, is shown caring for a fellow worker, Anna, who is dying in sin. Anna would like to have her mother near her but she is ashamed of her condition, because she knows her mother could not see her in a house of prostitution : «Vorrei mia madre, ma nessuno di quelli che amiamo può venire qui... Se venisse non potrei guardarla. Mamma, tanto buona.Tutte le mamme sono buone, anche la tua ». (I'd like to have my mother here, but none of the people we love can come here... if she came here I could not look at her. My mom, so nice. All mothers are nice, yours too)

Maria cries upon hearing Anna's words and thinks about her own mother. Anna calls out for her mother and wants a crucifix with which to pray ; eventually she dies in hospital. The movie, thanks to a dream, then presents a long flashback, during which we learn about Maria's past. Back in her village Maria is pregnant before marriage and leaves her mother to spare her the shame, hoping to get married and repair her sinful act, but the father of the baby abandons her so she finds help in a Casa della madre e del fanciullo [House of the Mother and Child] (Figure 3). Maria is shown breastfeeding her baby in a modern and efficient facility, all devoted to newborn babies and their mothers ${ }^{22}$. ONMI was a strong promoter of breastfeeding, which was the preferred choice for nursing babies. As noted by Saraceno, in ONMI ideology breastfeeding was in itself the guarantee of a good mother, who was willing to sacrifice herself for her baby and accept the rules of nature. It was also considered helpful to establish more bonding between

\footnotetext{
${ }^{21}$ The film was well received by contemporary critics, see M. NICOLETTO's remarks (Donne nel cinema di regime. Fra tradizione e modernità, op. cit., p. 326, note 761). For more on this film as perfect example of cinematic melodrama see Orio CALDERON's «Il mélo tra vecchio e nuovo », op. cit. Fallen women will become more frequent in melodramas of the 1950s with films like Luigi COMENCINI's Persiane chiuse (1951), Augusto GENINA's Maddalena (1954), Raffaello MATARAZZO's La schiava del peccato (1954) and Vortice (1954).

${ }^{22}$ Also in the opening scene of Mario Camerini's T'amerò per sempre (1943) we see a maternity ward full of babies and nurses tending them, in a scenario of clinical hygiene and modern care. These scenes remind us of the documentary-style LUCE Newsreels, produced for the edification of women in their role as mothers of new children for the Fascist nation.
} 
mother and baby, particularly for unmarried mothers ${ }^{23}$. Alongside her own baby, Maria breastfeeds Tonino, a baby whose mother is too sick to nurse. Tonino's father, the peasant Andrea, trusts this centre and Maria more than a balia in the countryside. As Maria breastfeeds both babies, she shows her generosity and spirit of sacrifice. When Maria's own baby gets sick and is taken to the infirmary, she is not allowed to stay with him, and does not see him die. Later her cradle is shown empty. Maria has lost her child but she nurses and cares for Tonino until he is weaned and learns to walk. She knows that Tonino will return to his mother and his family at the farm, when he is old enough. When the parents come to pick up their son, Tonino's mother, Adele, is very grateful and attributes to Maria the generosity and devotion that only a mother can understand : «Soltanto una mamma può capire quello che avete fatto » (« Only a mother can understand what you have done »). Since Maria knows the boy so well and has nowhere to go, Tonino's father offers to let her stay with them in the countryside. Maria accepts this arrangement and works hard caring for Tonino, to whom she is very attached. Unfortunately, Maria's only sinful act marks her entire existence with misfortune and with exploitation on the part of most men she meets. She ends up in the brothel of the film's opening scene. Maria's role as a wet nurse and vicarious mother is limited to a short part of the movie, however it contributes to the identification of Maria with the type of the sinner as Madonna or Mary Magdalene, a fallen woman on the path to redemption ${ }^{24}$. In the end, Maria rejects her abject life in the brothel and decides to return to her village, to be reunited with her aged mother. Maria, now back in the maternal home, calls out to her mother, just like Anna at the beginning of the movie, but here the crying daughter and mother hug each other. Although Maria was a vicarious mother, as the title La peccatrice suggests, she remains a sinner because she got pregnant outside of wedlock. Maria's entire existence is a series of unfortunate events, which serve as punishment for her transgression and drag her down into a spiral of bad experiences that lead her into prostitution. In every instance, Maria suffers much unjust treatment, especially at the hands of men. Despite her goodness and generosity, she cannot aspire to agape, so her only choice is to return to the maternal home. Maria is seen only briefly acting as a wet nurse, but this part of the movie has also a documentary value, in that some of the scenes are shot in a Casa della madre e del fanciullo where she nurses the baby.

${ }^{23}$ Chiara SARACENO, « Costruzione della maternità e della paternità » in A. DEL BOCA, M. LEGNANI, M. G. ROSSI (dir.), Il regime fascista. Storia e storiografia, op. cit., pp. 475-497.

${ }^{24}$ See the interpretation of Marcia LANDY (The Folklore of Consensus. Theatricality in the Italian Cinema. 1930-1943, Albany, State University of New York Press, 1998) especially page 269. 
Just like Mamma Rosa, Maria has lost her own baby, and the task of caring for another child provides comfort for her loss. The act of breastfeeding has created a special bond with the putative son and has shown the generosity and sacrifice of the vicarious mother. But the natural mother comes to claim her son, and for Maria there is nothing left to do. Her virtuous conduct is not sufficient to erase her transgression, but in the finale Maria has taken the path to atonement and in this sense she is a kind of Mary Magdalene figure.

\section{Vicarious Mothers in Ballerini and Poggioli}

In La fuggitiva and Sissignora, the vicarious mothers are young women, who are neither wives nor mothers, nor wet nurses. Delfina Carli (Iole Voleri) and Cristina Zugno (Maria Denis) are two orphans who are mishandled by the people who surround them, but they still keep their good heart and reveal a maternal instinct that leads them to put the good of the child ahead of their own and above all else.

In La fuggitiva, adapted from the eponymous novel by Milly Dandolo, Delfina Carli suffers all sort of humiliations and sacrifices herself for the sake of the young girl, Marina Ravaldo (Mariù Pascoli $)^{25}$. Marina is the fugitive girl that Delfina finds outside her friend's millinery shop. Delfina is able to take the girl back home and becomes immediately attached to her, so much so that her father offers Delfina the chance to work as a nanny (Figure 4). Delfina, who is alone in the world, and has just quit her job to marry a man, who then rejected her at the altar, accepts the offer. Although Delfina develops deep affection for the girl and begins a sentimental liaison with her father (attracted to her as a potential mother for Marina), she decides to leave Marina and the Ravaldo home when the estranged biological mother, the chanteuse Vanda Reni (Anna Magnani), reveals to Delfina that she has hopes of reuniting with her daughter and eventually marrying Antonio Ravaldo. Delfina understands the right of the real mother and breaks her relationship with the girl and with Ravaldo to make way for Vanda's redemption. In her good heartedness, Delfina even takes Vanda to visit her sick daughter, a sign of Delfina's generosity and selflessness, but in her delirium Marina calls out Delfina's name. Delfina is depicted as a sort of

\footnotetext{
${ }^{25}$ For more on this film and on the difference between book and film see my article « Children in Fascist Regime Cinema : The Case of Luigi BALLERINI's La Fuggitiva (1941) » Quaderni d'italianistica 342 (2013), pp. 1136. See also Danielle HIPKINS « Girls Lost and Found : Daughters of Sin in Italian Melodrama of the 1950s » in D. HIPKINS and Roger PITT (dir.), New Visions of the Child in Italian Cinema, Bern, Peter Lang, 2014, pp. 189218.
} 
Marian figure ; she sacrifices herself in the name of the right of the mother to return to her child. At the end of the film, Delfina is seen with her long-lost grandfather in church on Christmas day. We watch Delfina wearing a veil, with tears in her eyes, looking at the Madonna and child, while we hear the music of Schubert's Ave Maria in the background. In this finale, the glorification of the surrogate mother as a type of Madonna, a model of self-sacrifice, is emphasized by the iconography and the music. The audience is invited to see the identification between Delfina and the Virgin Mary, the mother par excellence and a paragon of altruism and self-abnegation. Delfina is presented in contrast with the biological mother, who is shown as an example of bad motherhood : Vanda, like Kiki in Le due madri, is the eroticized, sensual woman who works in the show business. Vanda gave up Marina to pursue a career as a cabaret dancer, but still hoped to get married to Marina's wealthy father, who pays her generous sums of money. Vanda is a type of wayward woman, she is not a prostitute, but her name, generally attributed to women of the world, her appearance - revealing clothes and elaborate headpieces - and her smoking, all contribute to the identification with a morally reprehensible woman, not fit for motherhood. This film reflects what Landy calls the classic elements of the woman's film : « the tension between desire and self-sacrifice, the incommensurability between the world of entertainment and that of domesticity $»^{26}$. In the Fascist ethos, femininity cannot be dissociated from the traditional family life and values, therefore a woman like Vanda Reni, or Kiki Valeri, who works as a variety show performer, cannot be a good wife or mother. In these films featuring the vicarious mother, the biological one is portrayed as absent, or too entrenched in her desire for independence, career or romance, while the vicarious mother is a model of virtue and generosity, a feminine type far superior to the real mother. Parallels with the iconography of the Virgin Mary are strong, and connect the mythology of motherhood with the Christian symbol of maternity and sacrifice. Delfina, like most vicarious mothers of Regime cinema, gives up the 'adoptive' child in order to allow the biological mother to take the role that is granted to her through the direct blood line, linking her to the child. However at the end of Ballerini's film the biological mother is not reunited with her daughter, precisely because she is a bad mother. Furthermore Delfina rejects a proposal that she should join Antonio Ravaldo and Marina and the film remains open-ended. While Delfina returns to the mountain village where her only relative, her grandfather, lives.

In Sissignora, adapted from the eponymous novel by Flavia Steno, Cristina, an orphan whose only relative dies in hospital, gets support from Sister Valeria, the nun who runs the Tutela della

${ }^{26}$ M. LANDY, The Folklore of Consensus. Theatricality in the Italian Cinema. 1930-1943, op. cit., p. 264. 
giovane, a religious organization that helps orphans girls find employment. Cristina's first job is in the house of the old Robbiano sisters (Emma e Irma Gramatica), two demanding and selfish middle-class women, who fire her very quickly, when they discover the relation between her and their only nephew, the sailor Vittorio. Cristina's low social class is not acceptable for a marriage to their nephew. Cristina is forced to change households several times before she finds a stable occupation, eventually working for a young widow, Signora Valdata, mother of little Giorgetto, to whom Cristina becomes very attached. Unlike the other orphans from the Tutela della giovane, who need employment but refuse jobs in houses with children, Cristina is naturally attracted to children and does not mind the hard work. Her love for children is evident also in her fondness for Giuliana, the little daughter of her friend Maria, a girl raised in an orphanage, because Maria had her out of wedlock.

When Giorgetto falls ill with scarlet fever, it is Cristina who takes care of him and saves him, while his biological, bad mother systematically avoids maternal duties and only worries about her relationship with her selfish and superficial lover, a man who dislikes children and is afraid of catching diseases. During a visit to little Giuliana's orphanage, Cristina is holding the little girl in her arms, exactly at the moment when Vittorio drops by, causing him to suspect that Giuliana might be Cristina's daughter (Figure 5). Vittorio soon realizes that the girl is Maria's and that his beloved Cristina is pure and untouched by sin. Cristina is so attracted to children that, while visiting the orphanage, she invites Vittorio to enter the chapel where many young children are singing and praying. Veiled and with her hands clasped in prayer, Cristina reminds the viewer of the Virgin, a pious and honest young woman, full of compassion and good feelings, a perfect future wife and mother. Cristina calls Vittorio to pray for the Virgin's help. A close-up of veiled Cristina contributes to her identification with the mother of Christ.

But marriage between Cristina and Vittorio is not in the cards, because she belongs to a lower social class. Vittorio's aunts are determined to end their relationship, so they ask Sister Valeria to summon the young woman and ask her to break it off with their nephew. Although Cristina and Vittorio love each other, his aunts think that she will ruin his future, because she is just a servant. Sister Valeria lectures Cristina on the value of her sacrifice and asks her to let Vittorio go : her generous heart can offer a more durable gift to God through renunciation. The nun stresses Cristina's hard life experiences that make her a good candidate for this sacrifice. The sister reassures the young woman that she will find a man more suitable to her condition. Reluctantly and with great sorrow, Cristina promises to let Vittorio go and tells him to end the affair, so that he can be reconciled with his family. As Landy observes in Sissignora, " upper class 
women are portrayed as indifferent, dishonest and cruel and the church offers no consolation and mitigation to her condition $»^{27}$.

While Giorgetto's doctor recommends that Cristina be kept at fair distance from the infectious boy, his selfish and frivolous mother disregards this rule to avoid displeasing her lover. Cristina generously assists the feverish boy, while his mother, spends time with her lover. Giorgetto becomes very attached to his nanny and we see him call her name instead of his mother's (Figure 6). When Cristina returns home, inconsolable after breaking up with Vittorio, who is embarking on his next sea voyage, she is very ill. The doctor, who is calling on Giorgetto, declaring him out of danger, detects a high fever in Cristina and suspects that she has been infected.

He lays blame on Signora Valdata, who made Cristina assist the sick boy at night, despite the doctor's recommendations against it. The doctor berates the mother and recognizes Cristina's generosity : «Questa ragazza ha ben saputo scarificarsi per il vostro bambino, è lei forse che l'ha salvato » (« This girl knew how to sacrifice herself for your child, it is probably thanks to her that he is saved »). Giorgetto's mother does not want to keep the sick nanny at her home, so the doctor calls an ambulance to take her to hospital. Before leaving, Cristina expresses her desire to say goodbye to Giorgetto. She bids farewell to the boy, who begins to cry, while his mother does nothing to comfort him. Cristina is very seriously ill, and since she has no family, Sister Valeria is informed about her poor health. In turn, the nun informs Vittorio's aunts, who reluctantly go and visit her, when it is too late, since Cristina is already dead. In the dramatic conclusion Cristina dies alone, in isolation, while her two girlfriends and Emilio, a friend from her same village, sit on a bench in the hospital's corridor, mourning her death. The young vicarious mother has made the ultimate sacrifice, she has died to save Giorgetto, whom she loved more than his biological mother does. This finale is especially dramatic since Cristina goes unrewarded for being so generous and caring. Landy rightfully observes that in this film of the last years of Fascism, death and illness are a metaphor for a society where power is visible and victims, like Cristina, are rendered invisible and with no possibility of amelioration. ${ }^{28}$

\footnotetext{
${ }^{27}$ M. LANDY, The Folklore of Consensus. Theatricality in the Italian Cinema. 1930-1943, op.cit., p. 284.

${ }^{28}$ M. LANDY, The Folklore of Consensus. Theatricality in the Italian Cinema. 1930-1943, op.cit., pp. 284-285. Ferdinando Maria POGGIOLI offers another variation of the vicarious mother type in the film La morte civile (1942). Here, it is the biological mother who acts publicly as a governess to the girl, who is in fact her own daughter. Rosalia does this in order to protect the girl's respectability, tarnished by a father who was jailed for murder. In this movie, the child is believed by the public to be the daughter of the doctor, whose wife died in childbirth. The biological mother serves as a nanny for the girl and lives close to her daughter, but lets everyone
} 


\section{Conclusion}

Under the Fascist regime woman and mother were viewed as one and woman had a public mission in maternity and fertility, and could carry out her duty only by producing, breast-feeding and raising healthy and strong children to support the power of the state. According to Fascist ideology, women best fulfilled themselves in the domestic sphere. The myth of motherhood created by Fascism was promoted through various social initiatives and institutions that fostered and protected maternity. The regime instituted public celebrations of motherhood such Mother's Day and public recognition of prolific mothers, it also created organizations such as ONMI, to enhance the demographic campaign and assist mothers and children. Despite the centrality of the mother in Fascist ideology, the cinema of the regime does not produce many films dealing with maternity and mothers. As critics have noted, LUCE documentaries and Cinegiornali on motherhood put more emphasis on the children or on the welfare institutions that provided assistance to the mothers, de facto giving to the figure of the mother less prominence.

The maternal melodrama is the genre of commercial cinema in which the mother makes its mark during the late 1930s and early 1940s. Among the various maternal figures, we find the vicarious mother, a woman who takes care of a child who is not her biological offspring. The surrogate mother fits well into the Fascist aesthetic of self-sacrifice, attached to the role of the exemplary woman and to the image of the Virgin, the ultimate example of abnegation and subordination. Vicarious mothers suffer the drama of separation from the surrogate child, in most cases they only live with their surrogate child for a short period of time, as we sees in $L a$ canzone dell'amore, Sissignora, La fuggitiva and La peccatrice. In Le due madri, a less melodramatic movie made earlier than the others, where we see two mothers competing for the same son (Salvatore), Mamma Rosa and Kiki, eventually live together with Salvatore's new family in the country village, where he marries his sweetheart and starts his family. This movie shows the most positive outcome for both putative mother and child, and reaffirms the values of the Fascist family. Salvatore was raised by a traditional, albeit vicarious mother, so he creates for himself a conventional family. It is remarkable that the best prospect for the vicarious mother is shown in Le due madri, a movie released in 1938, whereas in later films surrogate mothers disappear soon from the life of their putative children. In Palermi's La peccatrice Maria, having acted as a wet nurse to Tonino, soon sees the boy reunited with his biological mother and his family, while she,

believe that she is her governess. The film also illustrates the aesthetic of sacrifice on the part of the mother, who is willing to surrender her biological daughter in order to give her a better future. 
being a fallen but repented woman, is not worthy of a child and a family of her own, but can only return to her home village, to stay with her mother and begin her path of redemption. We see a link between wayward femininity and punitive removal of the child, especially when the mother was sexually transgressive. In La fuggitiva Delfina, by not accepting the marriage proposal of Antonio Ravaldo, deliberately gives up her role as vicarious mother and leaves little Marina alone with her cold father and insensitive governess, but there is no evidence that the biological mother is going to be reunited with her daughter. Since the film is open-ended we cannot predict whether Delfina will have a chance for a child and family of her own, but given her honesty and integrity we can presume that for her eros will lead to agape. The worst scenario for the vicarious mother is presented in Sissignora of 1941. In this film, Cristina, who is an honest and generous orphan, dies a short time after having taken care of the surrogate child. Cristina makes the extreme sacrifice to save her putative son. She is the ultimate example of abnegation : she is simply the victim of a world where her goodness is not rewarded. As the melodramatic tones increase over time, the mythology of motherhood in Fascist movies becomes more punitive, even to vicarious mothers, and leaves children (Giorgetto and Marina) in the hands of indifferent and distant parents, depriving them of the care of their good putative mothers.

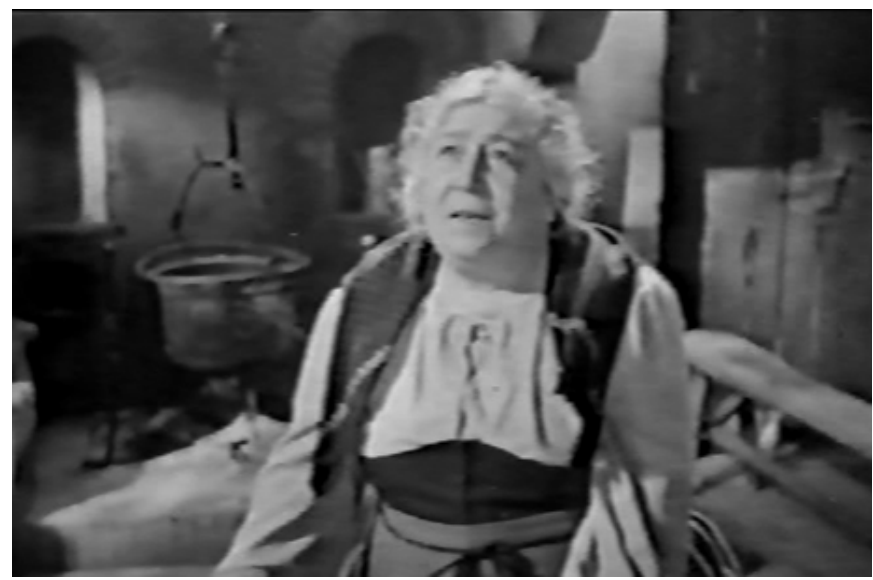

Figure 1 : Le due madri Mamma Rosa (Bella Starace Sainati) 


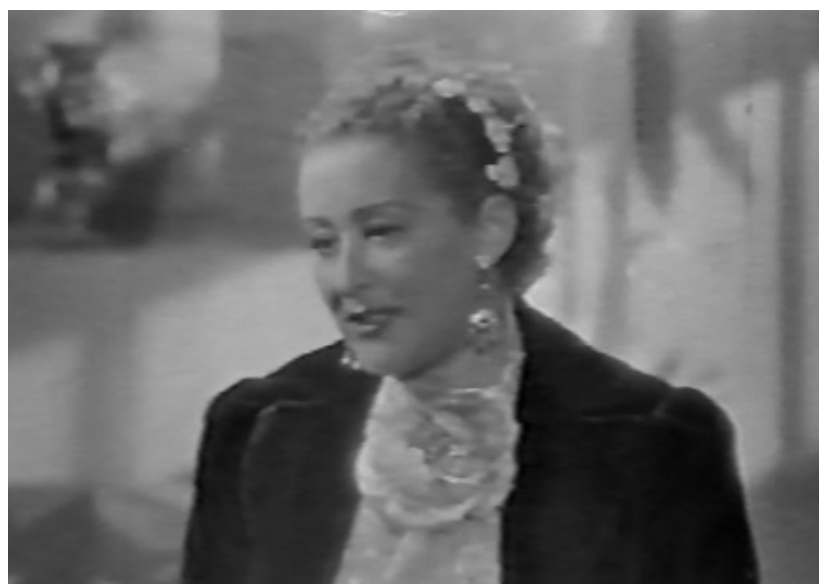

Figure 2 : Le due madri Kiki Valeri (Lydia Johnson)

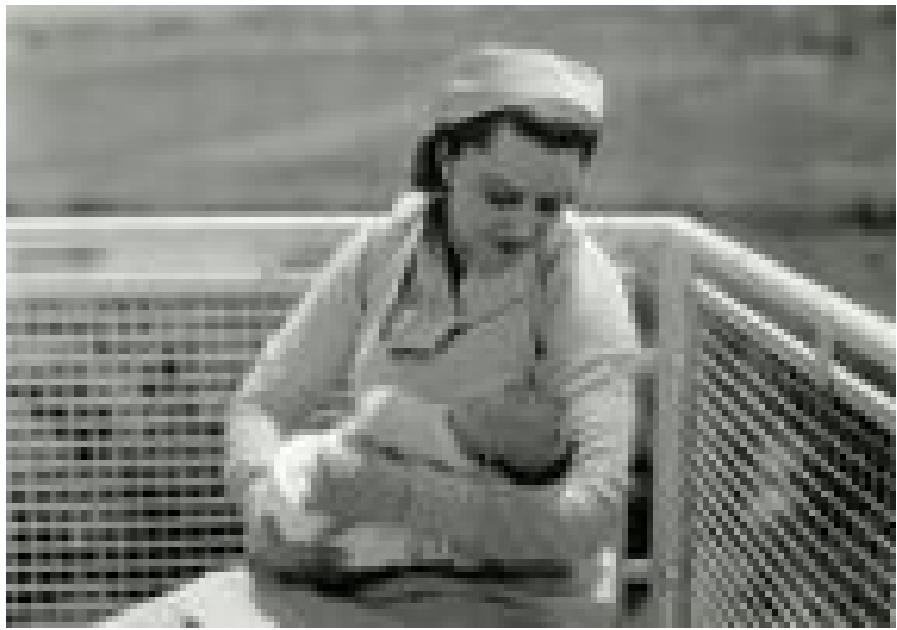

Figure 3 : La Peccatrice Maria (Paola Barbara) with her baby in the Casa della Madre e del Fanciullo 
III - Patrizia Bettella : Vicarious Mothers in Fascist Regime Cinema

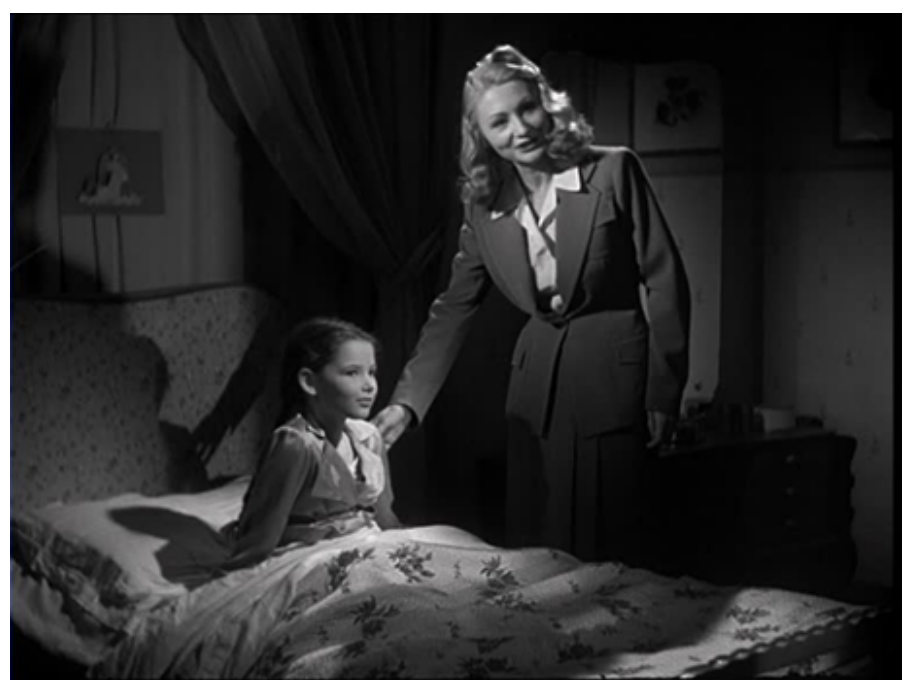

Figure 4 : La fuggitiva Delfina (Iole Voleri) and Marina (Mariù Pascoli)

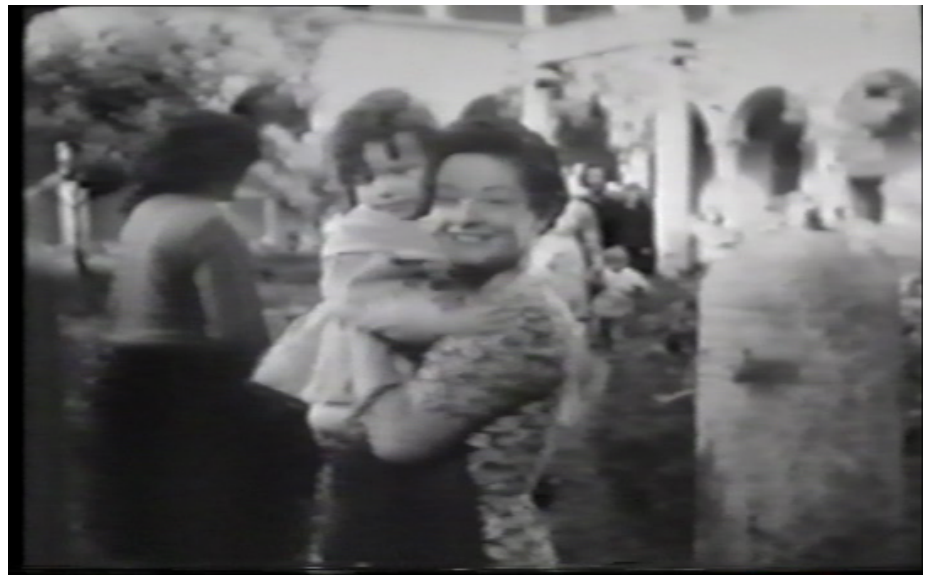

Figure 5 : Sissignora Cristina (Maria Denis) with Little Giuliana 
Mnemosyne, o la costruzione del senso $n^{\circ} 8$

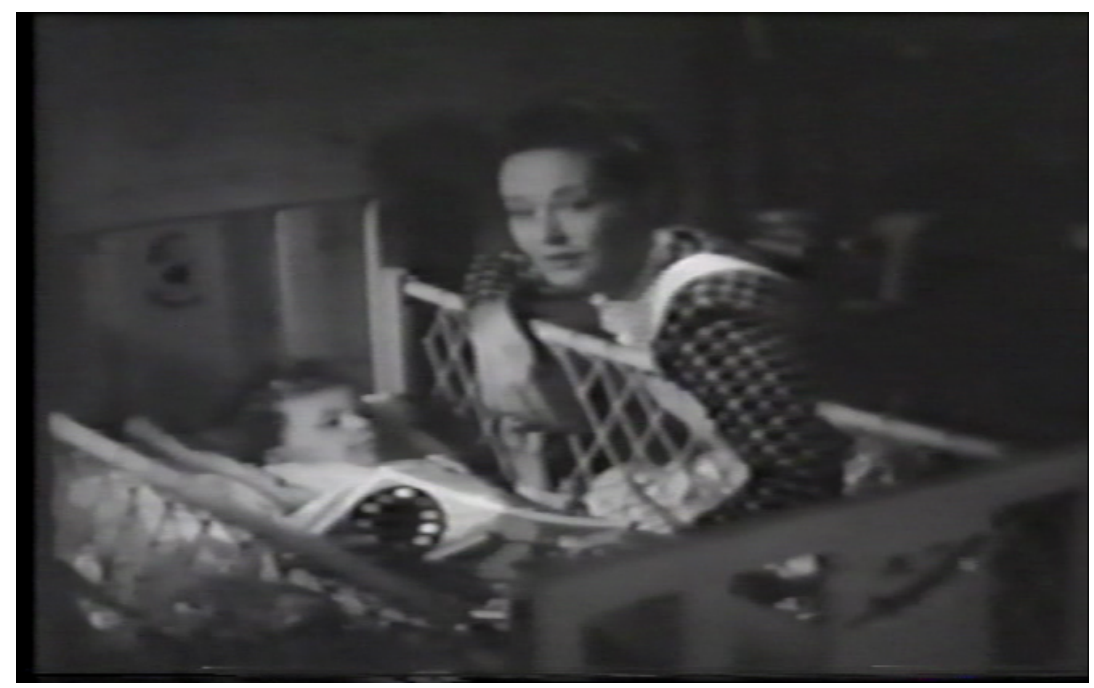

Figure 6 : Sissignora Cristina with Giorgetto 